\title{
The Role of Mobile Courts in the Enforcement of Laws in Bangladesh
}

\author{
Gazi Delwar Hosen* \\ Syed Robayet Ferdous ${ }^{* *}$
}

\section{Introduction}

Mobile court ventilates a praiseworthy neo-paradigm in the whole gamut of enforcing laws in the adversarial legal tradition of common law system in Bangladesh. The very outline of mobile courts, in terms of its structure, legal basis, modus operandi, functioning, efficacy, judicial activism, etc. are concerned, it is axiomatically proved that the mobile court is an admixture of inquisitorial and adversarial legal traditions of civil and common law legal system as a "hybrid legal system" for ensuring justice through dynamic implementation of law. Mobile court is probably the most popular and effective government institution to materialize the laws which is a core demand of millions of down trodden people in Bangladesh, thereby providing an avenue of hope for this nation. At the infancy stage of mobile court, we discover multi- dimensional problems in terms of its functioning, legal basis, logistic support, acceptance to the vested segment and people at large. But notwithstanding these multi-faceted acid tests, mobile court takes place an unparallel and distinctive place to protect and preserve consumer protection, sound public heath, law \& order situation and ultimately justice through the proper enforcing of existing concomitant laws. This is high time for all of us to launch profound research and investigations to find out its lacunae so as to establish a full-fledged and robust socio-legal background for mobile court so that it can work with its full bloom.

\section{What is mobile court?}

The word "mobile" is an adjective which means Capable of moving or of being moved readily from place to place and "court" generally signifies an institution in which disputes and conflicts are heard, argued and decided on the basis of law. In other words, court is an official, public forum which a public power establishes by lawful authority to adjudicate disputes, and to dispense civil, labour, administrative and criminal justice under the law. In common law countries, the courts are the central means for dispute resolution, and it is generally understood that all persons have a right to bring their claims

\footnotetext{
* Judicial Magistrate, Manikgonj.

** Lecturer, Department of Law and Justice, Southeast University, Dhaka.
} 
before a court. Similarly, those accused of a crime have the right to present their defenses before a court. ${ }^{1}$

So, mobile court connotes a special arrangement of the court which moves from place to place, as opposed to, the court in the enclosed place, to adjudicate laws for the ulterior purpose of ensuring justice.

According to Dr. Borhan Uddin Khan "mobile court can be compared as a mobile phone which is easily moveable to enforce laws as a supplementary and complementary maneuver of court as we understand Court derives from the Latin cohorts meaning a yard and the retinue or persons (a cohort) which gathered in the enclosed place. ${ }^{2}$

Mobile court is not a new phenomenon rather it has antique sporadic legacy in various statutes and legal traditions in Bangladesh and elsewhere like India, United Kingdom, etc. Think about the public examinations we appeared i.e., SSC, HSC, where magistrates visited the hall and sometimes punished some students or others for the offences committed under the Public Examination (Offences) Act, 1980; those magistrates acted as mobile courts. When a magistrate moves to the place of the offence committed and tries the case outside the courtroom then we say it is a mobile court. But the term Mobile Court or Traveling Court is not used in any law under which first class magistrate acts as a mobile court. Though it has no explicit legal reference in the book of law, the term received wide acceptance and formed part of our legal vocabulary.

\section{Legal basis of mobile court}

The term "mobile court" as such does not have any specific, explicit and defined legal edifice. But there are many scattered and sporadic legal provisions and legal traditions to provide the fertile ground of nourishing and patronizing mobile court for the utmost motive of public welfare and justice to which the state is committed and bound under the constitution. Let us have a diagnosis of conducting trial outside the courtroom by a designated judicial authority as per its legal basis.

\footnotetext{
${ }^{1}$ http://www.en.wikipedia.org/wiki/Court, Visited on November 202009

${ }^{2}$ Dr. Borhan Uddin Khan, Seminar on Role of Mobile Courts in the Enforcement of Laws in Bangladesh held on $2^{\text {nd }}$ June, 2007 at Law Faculty, Eastern University.
} 
Section 9(2) of the Criminal Procedure Code, 1898 says that government may, by general or special order in the official gazette, direct at what place or places the court of sessions shall hold its sittings. But there is no provision of official gazette notification for the specific sittings of magistrate courts. For this reason it will not be improper for magistrate if magistrate wants to try a case in the place of the commission of any offence. ${ }^{3}$

The magistrates' power and capacity to adjudicate within their offices' jurisdiction is not limited in a particular premises or buildings rather they can sit at any place to work as court to materialize law and justice as the milieu demands.

Sections 10, 11, 12, 13, 14, 15 and 18 enshrine the provisions of appointment of Chief Metropolitan magistrate, District Magistrate, Additional District Magistrate, Metropolitan magistrate, Magistrate of the first, second or third class, Upazila/Thana Magistrate, Special Magistrate, Benches Magistrate and their respective capacity and territorial periphery to adjudicate. ${ }^{4}$

Section 352 deals with the place in which any criminal court is held for the purpose of inquiring into or trying any offence shall be deemed an open court, to which the public generally may have access, so far as the same can conveniently contain them:

Provided that the presiding judge or magistrate may, if he thinks fit, order at any stage of any inquiry into, or trial of, any particular case, that the public generally or any particular person, shall not have access to, be remain in, the room or building used by the court. ${ }^{5}$

Section 33 A of Bangladesh Standard and Testing Institute (Amendment), Act specifically authorizes magistrates to work as mobile court.

Notwithstanding anything contained in the Code of Criminal Procedure, 1898 (Act V of 1898)

(a) an offence punishable under this ordinance may be tried at anyplace in the local jurisdiction of the Metropolitan Magistrate or of the Magistrate of the first class.

\footnotetext{
${ }^{3}$ The Code of Criminal Procedure, 1898

${ }^{4}$ Ibid

${ }^{5}$ Ibid
} 
(b) An offence punishable under this ordinance may be tried summarily in accordance with as far as possible the provisions laid down in chapter XXII of the said code. ${ }^{6}$

Section 41B of the same Act provides:

Notwithstanding anything contained in the Code of Criminal Procedure Code (Act V of 1898)

(a) an offence punishable under this ordinance may be tried at any place within the local jurisdiction of the pure food court.

(b) an offence punishable under this ordinance may be tried summarily in accordance with as far as possible the provisions laid down in chapter XXII of the said code.7Pure Food Ordinance (Amendment) Act, 2005.

The Fertilizer (Management) Act, 2006 is also a shimmering example which includes the pathos of Mobile court. These aforesaid enactments have included provisions where it is daylight clearly mentioned that offences punishable under these laws may be tried at any place within the local jurisdiction of the concerned court. The general and naïve trend is to conduct trial in an enclosed court house but there are no stereotyped inviolable laws to forbid the arrangement of trials at any place for the sake of justice in complex human dealings as it is demonstrated in multifaceted judicial discourses.

As per precedents pertaining to mobile court we discover, there are many judgments all over the world including Indian sub-continent. Trials should be conducted at a proper place which is a normatic matrix of justice paradigm. The trial magistrate has fully-fledged freedom to choose the place of trial. There are no hard and fast laws to conduct trials in an enclosed room or building rather it may occur in an open place where the offence has committed. $^{7}$

According to Zahirul Hoque -

The concerned empowered magistrate can conduct a trial even in the tiny corner of jail through a formal declaration, in accordance with the previous judgment of 21 DLR $310 .^{8}$

It was observed in the case of 1984 P.Cr.lj.273 (Kar.) that unless and until there is a question of frustration or miscarriage of justice, this is neither a compulsion nor a right of the parties to claim to change the place of trial.

\footnotetext{
${ }^{6}$.Bangladesh Standard and Testing Institute (Amendment) Act, 2003

${ }^{7} 21$ DLR 10, PLD 1962 Kar.249 (BD)

${ }^{8}$ Zahirul Hoque, Law and Practice of Criminal Procedure, $9^{\text {th }}$ Ed. Page 544
} 
It is the magistrate who has discretionary power to commence the trial at any place other the court house for the sake of justice. ${ }^{9}$ Normally court will be done in the court house but in special circumstances it can betaken place else where. $^{10}$

According to Zahirul Islam -

There is no provision in the Cr.P.Code which compels a magistrate to hold his court in the usual court room. Section 352 probably contemplates that a magistrate can hold his court anywhere he likes. But the magistrate wherever he may be compelled to sit by executive order, is bound by the provisions of Sec. 352 and he must realize that the place where the trial is held must be something like an open court to which the public generally may have access so far as the same can conveniently contain them. The discretion to exclude the public generally or any particular person at any stage of any inquiry or trial must be a judicial discretion exercised by him. If the magistrate cannot not have the absolute right to regulate the proceeding at the place where he is holding the trial, he ought not to hold the trial or inquiry there. ${ }^{11}$

When there is a question of pardanashin lady, her testimony would be taken in her defined place. ${ }^{12}$ According to Rokon-ud-Doula -

Though the phenomenon of mobile court conducted by Magistrate is not explicitly stated in any law, as it is defined in Article 152 of Constitution of the Peoples' Republic of Bangladesh, there are no negative sayings in the law. ${ }^{13}$

So it is axiomatically proved that magistrate court can act as what we called mobile court on the basis of scattered indirect laws and legal traditions as prevail in the Indian sub-continent and elsewhere. Besides all these dimensions, if we ponder over enforcing laws for the ulterior purpose of justice by mobile court and its wider acceptance to the people at every strata of the society we can impose a prolific and fertile legal ground for smooth functioning of mobile court in Bangladesh.

\section{Expressed mysticism of popularity of mobile court}

Mobile court creates a revolutionary change in the history of materialization of laws which is a rudimentary and basic problem for the availability of justice in Bangladesh. Articles 18, 19 of the constitution of the peoples'

\footnotetext{
${ }^{9} 21$ DLR 307

${ }^{10} 1987$ Cr.LJ 1922

${ }^{11}$ The Code of Criminal Procedure $4^{\text {th }}$ ed. Page 853

12 (2 Weir 432)

${ }^{13}$ Pivotal Harbinger of the episode of mobile court and magistrates of the CMM court, 'On mobile court: basis and law' in Monthly "Itihash Oanesha” March-2007
} 
republic of Bangladesh specifically mentioned about protection and preservation of public health which is in a substantially vulnerable and fragile situation. Within this life threatening and perishing reality of life and futility of justice, the mobile court comes with a glittering light of enforcing laws with transparency, accountability. Everybody knows that something is wrong in the foods we usually buy from the market. But we did not know before the active operations of mobile courts that how adulterated the foods were? Survey result of the Institute of pubic health will help us to realize how vulnerable we are:

Result of survey by Institute of public health

\begin{tabular}{|c|c|c|}
\hline Year & Sample collected & Percentage of adulteration \\
\hline 2000 & 3280 & $47 \%$ \\
\hline 2001 & 4582 & $52 \%$ \\
\hline
\end{tabular}

Mobile courts have done a very commendable job by unearthing the scenario whereby innocent consumers are deceived and revealed the unscrupulous and immoral character of our business community. For this reason the mobile courts became popular. Mobile court creates a revolutionary change to enforce laws in the country by arranging spot and prompt judgment which rejuvenate the trust among the citizens towards the judiciary. It is the mobile court which proves its authenticity to bring the criminals into the books and enhance government revenue through the collection of huge amount of compensation from the demeanors.

Mobile court echoes the very heart rendering appeal of the mainstream community of Bangladesh through commitment, justice with equity and law, honesty and inner sanction of the offices. Successes of mobile courts lie on the honesty and sincerity of the concerned magistrates in many parts. Indeed it is the magistrate who plays an important role in effecting and implementing laws and thus an honest, efficient and sincere magistrate would, for all practical purpose be most equipped to administer the relevant laws.

Magistrate of WASA under the Water Supply and Sewerage Authority Act, 1996 has the power to impose fine for the violation of WASA Act. Before the appointment of Wasi Uddin as a magistrate of WASA, in 11 years his predecessor collected only 65,500 taka whereas Wasi Udiin in his tenure of about 2 years collected 72,66,775 taka as fine which shows that how sincerity and honesty of a magistrate can contribute to the proper functioning of mobile courts. 
The Role of Mobile Courts in the Enforcement of Laws in Bangladesh

\begin{tabular}{|l|c|c|c|c|c|}
\hline Period & $\begin{array}{l}\text { Duration } \\
\text { (Years) }\end{array}$ & $\begin{array}{l}\text { Cases } \\
\text { Filed }\end{array}$ & $\begin{array}{l}\text { Total Fine } \\
(\text { Tk) }\end{array}$ & $\begin{array}{l}\text { Minimum } \\
\text { Fine (Tk) }\end{array}$ & $\begin{array}{l}\text { Maximum } \\
\text { Fine (Tk) }\end{array}$ \\
\hline $1995-05$ & 11 & 83 & 65,000 & 50 & 10,000 \\
\hline $2005-07$ & 2 & 117 & $72,66,775$ & 1000 & $4,66,250$ \\
\hline
\end{tabular}

\section{Mobile court's function under different laws}

Mobile courts are now dispensing their functions under various laws. With the continuous success of initially established mobile court for the purpose of anti adulteration drive, Government has already expanded its area and invests powers under different laws. The mobile courts are placed at strategic points of the city and they examine fitness of motor vehicles, driving licences, standards of edible food items and take appropriate punitive measures on the spot. The laws under which mobile court can perform its duties are:

1. Penal Code, 1860

2. BSTI Ordinance, 1985

3. The Pure Food Ordinance, 1956

4. Dhaka City Corporation Ordinance, 1983

5. The Drug Control Ordinance, 1982

6. The Standard of Weights and Measures Ordinance, 1982

7. Fertilizer (Management) Act, 2006

8. The Special Powers Act, 1974

9. Fixation of Price and Distribution of Essential Commodities Ordinance, 1970

10. The Bangladesh Control of Essential Commodities Act, 1956

11. The Breast Milk Substitute (Regulation of Marketing) Ordinance, 1984

12. The Dangerous Drugs Act, 1930

13. The Trademark Act, 1940

14. Water Supply and Sewerage Authority Act, 1996

15. Dhaka Electricity Supply Authority Act 1990

16. The Protection and Conservation of Fish Act, 1950

17. The Motor vehicles ordinance 1983,

18. Tobacco control Act, 2005

19. DMP ordinance, 1976

20. Bangladesh essential Services Ordinance, 1958

21. The animal Slaughter (Restriction) and Meat Control Act, 1957

22. Guest Restriction Ordinance, 1984

23. The Cinematograph Act, 1918

24. The Electricity Act, 1910 
25. The Marine Fisheries Ordinance, 1983

26. Brick Burnt (Restriction ) Act, 1989

27. Preventing Iodine Deficiency Diseases Act, 1989

28. The Bangladesh Wild Life (Preservation) Order,1973

29. The Gambling Act, 1867

30. The Public Examinations (Offences)Act, 1980

31. Environmental Court Act, 2000

32. The Prohibition of Smoking in Show Houses Act, 1952

33. The Protection and Conservation of Fish Act, 1950

34. Labour Act,2006

35. The Railway Act, 1890

\subsection{Most popular areas of functioning}

In the following four fields actions taken by mobile courts got admiration.

1. Anti adulteration drive

2. Eviction of Illegal establishments

3. Collection of Arrears

4. Protection of Environment

5. Transport and Vehicle Sector

From unhygienic environment of a restaurant to formalin mixed fish, from banned polythin bags to Jatka fish, from counterfeit cosmetics to rotten wheat, from bogus physician to date expired life saving medicine; mobile court revealed the dishonest and utterly chaotic situation of the business community of Bangladesh. Reputed private business firm to government owned or managed farm (milk vita co-operative farm), no one is found dependable.

There is no definite information as to how many illegal constructions are there in government property or establishment without legal permission. Almost all lakes (12) in Dhaka city are occupied even rivers are not escaped. Hundreds of millions of taka is due to the subscribers of different government owned service providing organizations, realization of which was previously very complicated and time consuming. DESA and WASA are now collecting their bills and cutting off illegal and defaulters' connections.

\section{Procedure of trial by Mobile Court}

Mobile court disposes most of the cases summarily. Section 262 of the Criminal Procedure Code provides that in trying a case summarily, summary procedure laid down in chapter XX shall have to follow. According to this 
chapter if a case is disposed summarily maximum punishment that can be awarded is two years of imprisonment. In the recent years some Acts have given power to sentence more than two years to mobile court.

Although the object of summary procedure is to shorten the course of trial, it is nevertheless incumbent on the Magistrate to put on record sufficient evidence to justify his order. The courts record the substance of the deposition of the witnesses and also write out a short judgment.

In practice, mobile courts perform their function very summarily than usual summary trial as the court itself visits the spot, apprehends the offender red handed, examines the witnesses, hears the accused, completes the procedural requirements and passes a sentence instantly. To examine whether any illegal activities are committed by the accused the court is accompanied by the experts or officials of relevant fields.

The information of any offence under the jurisdiction of mobile court comes from various sources. They are the general people who are helping enormously by providing information related to manufacturing illegal or unauthorized goods. In this regard the contribution of electronic and print media is enormous. They have constantly raised awareness among general people on the issue.

\section{Horizontal successes of mobile court to enforce laws}

The offenders who had hardly been punished for the violation of different laws are now facing trial and sentenced regularly due to the active operations of the mobile courts. The offences under BSTI Ordinance which mobile courts have put into action are-

- Improper use of standard mark.

- Export of prohibited or restricted articles.

- Sale and distribution of articles prohibited.

- Penalty for obstructing inspector in discharging his functions, etc.

The offences under the Penal Code which mobile courts have put into practice are-

- Adulteration of food or drink intended for sale

- Sale of noxious food or drink

- Adulterations of drugs 
- Sale of adulterated drugs

- Sale of drugs as a different drug or preparation

The offences under the Pure Food Ordinance (Amendment) Act which mobile courts have put into operation are-

- Manufacture and sale of adulterated food

- Sale and use of formalin, intoxicated food color etc.

- Manufacture or sale of food not of proper standard or purity

- Keeping adulterants in place where food is manufactured or sold.

Activities of mobile courts encourage Government to amend existing laws to widen its area of functioning and powers. In the year of 2005 Government amended Pure Food Ordinance of 1959 and reset the offences and sentences. Under this act the imprisonment and fine for different offences are:

\begin{tabular}{|c|l|l|l|}
\hline Punishment & & Minimum (Tk) & Maximum (Tk) \\
\hline \multirow{3}{*}{ Fine } & First offence & 2,500 & 75,000 \\
\cline { 2 - 4 } & $\begin{array}{l}\text { Subsequent } \\
\text { offence }\end{array}$ & 25,000 taka & $3,00,000$ \\
\hline \multirow{3}{*}{ Imprisonment } & First offence & 3 Months & 2 Years \\
\cline { 2 - 4 } & $\begin{array}{l}\text { Subsequent } \\
\text { offence }\end{array}$ & 1 Year & 3 Years \\
\hline
\end{tabular}

BSTI Ordinance has also been amended making the offences under BSTI ordinance more strict and incorporated new offences. A Magistrate working under BSTI ordinance has now been given specific authority to try cases at any place.

\section{Statistics of the regulatory activities relating to the qualitative standard of goods}

This statistics will show how the activities of mobile courts help in the enforcement of the BSTI ordinance. It should be kept in mind that BSTI (Amendment) Act, 2003 makes the function of mobile courts easy and effective.

\begin{tabular}{|l|l|l|l|l|l|}
\hline & $2002-03$ & $2003-04$ & $2004-05$ & $\begin{array}{l}2005- \\
06\end{array}$ & $\begin{array}{l}\text { 2006-07 } \\
\text { (July - Feb) }\end{array}$ \\
\hline
\end{tabular}


The Role of Mobile Courts in the Enforcement of Laws in Bangladesh

\begin{tabular}{|l|l|l|l|l|l|}
\hline $\begin{array}{l}\text { Number of } \\
\text { mobile courts }\end{array}$ & 250 & 420 & 383 & 700 & 421 \\
\hline Case filed & 35 & 279 & 696 & 1391 & 910 \\
\hline Case resolved & 19 & 243 & 555 & 1133 & 740 \\
\hline $\begin{array}{l}\text { Fine realized } \\
\text { (lakh taka) }\end{array}$ & ------- & 27.25 & 77.28 & 255.80 & 253.76 \\
\hline $\begin{array}{l}\text { Imprisonment } \\
\text { (persons) }\end{array}$ & ------- & ------- & ------- & 15 & 19 \\
\hline
\end{tabular}

Verification of weights and measures of petrol pumps under the BSTI (Amendment) Act 2006 is now the responsibility of the BSTI where mobile courts are playing important role. The statistics of verification of weights and measures (metrology) from 2002 to February 2007 are now projected below:

\begin{tabular}{|l|l|l|l|l|l|}
\hline & $2002-03$ & $2003-04$ & $2004-05$ & $\begin{array}{l}2005- \\
06\end{array}$ & $\begin{array}{l}2006-07 \\
\text { (July - Feb) }\end{array}$ \\
\hline $\begin{array}{l}\text { No of Courts } \\
\text { operated }\end{array}$ & 256 & 395 & 432 & 947 & 496 \\
\hline Cases filed & 2467 & 2890 & 3001 & 5667 & 1982 \\
\hline $\begin{array}{l}\text { Cases } \\
\text { resolved }\end{array}$ & 2467 & 2890 & 3001 & 5667 & 1982 \\
\hline $\begin{array}{l}\text { Fine realized } \\
\text { (lakh Taka) }\end{array}$ & 24 & 32.28 & 46.33 & 189.21 & 199.93 \\
\hline
\end{tabular}

\section{Citizens' expectation from mobile court}

Day by day expectation towards the mobile courts is increasing in at geometrical scale. Among them the following areas demand high degree of focus -

1. Workers who work in an unlawful factory or factory which makes adulterated food are arrested. We hope that the offences of these poor employees who don't have any choice but to work for their survival will be considered with sympathy and get free on humanitarian ground.

2. CNG and Taxi Cab drivers always claim more money than what is due in the meter and don't want to go everywhere. We sincerely hope that mobile court will seriously look into the matter and take steps to arrest the trend and impose penalty. 
3. The mobile courts can also play an important role if permitted by the government, in ensuring that all classes at Govt. colleges and public universities are held regularly and in time. In this regard educational environment of the private universities may be examined.

4. There are allegations that Government offices do not provide services they are supposed to do. Government may empower mobile courts to find out which officer is not present in his office or which officials are insincere in their work or wasting time by reading newspaper leaving the files incomplete.

5. In case of Environmental protection and preservation, the mobile court can take place a vital role

6. Last but not the least the mobile court should come forward with pragmatic solutions of effective law enforcement as the circumstances demand.

\section{Problems / impediments of Mobile Court}

No explicit provision of law: The mobile court does not have explicit legal basis rather it has a vague, passive, indirect, precedent, public welfare, high degree of acceptability and inductive maneuver to work with high command of popularity. But the fragile legal tradition, lack of legal knowledge and vulnerable socio-economic reality demands the legible and easy identified legal provision.

Lack of human resource: Scarcity of man power is the fundamental problem of mobile court. Only 8-9 magistrates are working in this vast area of fragile law enforcing situation in addition of their of mainstream formal court activities.

Lack of logistic support: Though mobile court has highly laudable and praiseworthy contributions, but it suffers from multi-faceted problems of scarcity of logistic support. It does not have necessary vehicles, support staff, additional expenditure, etc.

Lack of pubic awareness: We mark non co-operation and antagonistic views from the various segments representing vested interest. The business community, uneducated poor community, black marketer, cupidity, corruption, ethical waning, decadent of values, lack of inner sanction, etc. germinate many practical impediments and confrontational stands for mobile court. 
Lack of comprehensive approach: The functions, outline, structure and forseeability of the mobile court are very fragile, sporadic and short sighted. In the long term it may not have sustainability and suffer from adaptability in the future changing circumstances.

Lack of liaison and combination between and among multi-dimensional stakeholders: In the functions of mobile court we visualize the absence of holistic approach of combination and liaison between and among the various stake holders of the country and it often results in various bitterness.

Lack of monitoring mechanism: Monitoring mechanism is the touchstone of success of any plan and project. In case of mobile court, this monitoring mechanism is virtually absent.

\section{Recommendations for effective functioning of mobile court}

1. Class I magistrates or sessions judges will be placed in each court, with power to follow the procedure of summary trial as prescribed in the Code of Criminal Procedures

2. For dynamic and time-be-fitting mobile court there should be a combination of representatives from Metropolitan Police, Bangladesh Standards \& Testing Institution, Bangladesh Road Transport Authority, Dhaka City Corporation, Directorate General of Health and Bangladesh Rifles, under the supervision of magistrates.

3. More human resource and logistic support should be provided

4. Specific legal provisions should be made

5. Adjective or procedural law should be made.

6. Massive awareness program should be taken to enhance civic knowledge and to cooperate with mobile court.

7. Modern and scientific technologies should be provided.

8. Proper monitoring mechanism should be launched

9. Media participation and involvement should be extended

\section{Concluding Remarks}

Mobile court brings a neo-dimension and a significant paradigm shift in the enforcement of laws in Bangladesh for the utmost consideration of justice. For long we have seen that the aggrieved people get delayed remedy and that the offender's punishment is not commensurate with the degree of offence committed, in some cases they even go Scot free. Adulteration calls for severe 
punishment as public who consume these for long may fall victim to very serious ailments, as serious as cancer, thus it is imperative that mobile courts continue their good work in society so that confidence of public in law is reinstated. The eclectic amalgamation of Adversarial and Inquisitorial legal traditions of Common and Civil Law legal system reflected in Mobile Court episode creates a Hybrid legal system which proves its high degree of efficacy and prolific ness to materialize law to get the real flavor of justice. This phenomenon will ventilate, rejuvenate and strengthen the oath of patriotism and enhance the feelings of collectivity. The concerned state machineries, designated authority, civil society and other stake holders should take combined venture to eliminate the problems of mobile court. But one important aspect should be remembered with caution that mobile court is neither a substitution of mainstream court nor a panacea to enforce law as holistic approach rather it is a piecemeal and ad hoc maneuver in the existing chaotic circumstances of law and order situation. 